\title{
ArcheoSciences
}

Revue d'archéométrie

\section{Mapping the urban subsoil using ground penetrating radar - challenges and potentials for archaeological prospection}

Immo Trinks, Pär Karlsson, Anders Biwall and Alois Hinterleitner

\section{OpenEdition}

\section{Journals}

Electronic version

URL: https://journals.openedition.org/archeosciences/1630

DOI: $10.4000 /$ archeosciences. 1630

ISBN: 978-2-7535-1599-4

ISSN: $2104-3728$

Publisher

Presses universitaires de Rennes

\section{Printed version}

Date of publication: 30 October 2009

Number of pages: $237-240$

ISBN: 978-2-7535-0943-6

ISSN: $1960-1360$

\section{Electronic reference}

Immo Trinks, Pär Karlsson, Anders Biwall and Alois Hinterleitner, "Mapping the urban subsoil using ground penetrating radar - challenges and potentials for archaeological prospection", ArcheoSciences [Online], 33 (suppl.) | 2009, Online since 30 October 2011, connection on 21 September 2021. URL: http://journals.openedition.org/archeosciences/1630 ; DOI: https://doi.org/10.4000/archeosciences. 1630 


\title{
Mapping the urban subsoil using ground penetrating radar - challenges and potentials for archaeological prospection
}

\author{
Immo Trinks*, Pär Karlsson*, Anders Biwall* and Alois Hinterleitner **
}

Key words: GPR, Urban, Planning, Rescue archaeology.

\section{INTRODUCTION}

Over the course of centuries city centres have been continuously changing, developing and adapting to the requirements of society, architectural planning and advancing technology. Urbanisation increases the pressure on cities and towns, causing their expansion and demanding the exploitation of the limited space in their centres. This exploitation is endangering cultural heritage in the urban subsoil, posing a challenge for archaeological prospection to contribute to the preservation and documentation of hidden underground structures of archaeological and historical interest.

\section{The URBan SUbSOIL}

The urban subsoil consists often of many layers documenting the history of a place, keeping records of alternating phases of construction and destruction. In case of the acropolis of the legendary ancient city of Troy, Ilios, in northwest Turkey, at least 13 building phases have been documented archaeologically (Schliemann, 1881). At the site of the Viking age settlement and trading place Birka, which is considered to have been Sweden's first town, a cultural layer of in total two metres thickness has been built up over the 200 years of the town's existence between approximately 750 and $950 \mathrm{AD}$, corresponding to one centimetre per year (Björn Ambrosiani, 2006, personal communication). The shallow subsurface of modern cities contains reams of pipes, cables, rubble, backfilled excavation trenches and pits, cellars, wells, cavities, tunnels, graves and foundation walls of former houses, churches, monasteries and town fortifications. Underneath the tarmac of city roads and the paving stones of town squares layers of sand and gravel are criss-crossed with modern fibre optic and telephone cables and century old sewer pipes mixed with the debris of brick buildings. In layers with high levels of soil humidity or large clay content organic materials, such as wood, leather and bones can be preserved in good condition for many centuries. Urban soil layers as well as waste and latrine pits contain plant macrofossiles which convey exciting information about the menu and habits of our ancestors, the local flora and the spreading of exotic plants (Heimdahl et al., 2005; Heimdahl and Pettersson, 2007). Many of the central European cities have initially been made up to a large extent of houses built of organic materials, predominately wood, contributing to the devastating effects of frequently occurring blazes. Demands for fire safety as

* Swedish National Heritage Board, Archaeological Excavation Department. UV Teknik, Instrumentvägen 19, 12653 Hägersten, Sweden. (immo. trinks@raa.sel)

** Central Institute for Meteorology and Geodynamics, Vienna. 
well as fashion promoted the use of stones and bricks as building materials.

\section{Archaeological prospection OF URBAN CENTRES}

The archaeological geophysical prospection of urban centres which have been abandoned in the past and today are located under barren land pose different methodological possibilities and challenges compared to surveys conducted in modern city centres (Fig. 1).

While the first sites may successfully be prospected using aerial photography, magnetometry, ground penetrating radar (GPR), earth resistance, EM and seismic methods (e.g. Becker and Fassbinder, 1999; Nishimura and Goodman, 2000; Neubauer et al., 2002; Erkul et al., 2003) are these approaches difficult or impossible to employ in the latter case. The most promising non-destructive geophysical prospection method for use in modern urban centres is GPR. GPR measurements do not require coupling to the ground as in case of earth resistance surveys, they are much less affected by the presence of metallic structures compared to magnetometer prospection and they result in the largest amount of data of all commonly employed near-surface geophysical methods, providing detailed three-dimensional information about the subsurface (Leckebusch, 2003).

\section{Potential and Challenges of The GPR METHOD IN MODERN URBAN ENVIRONMENTS}

While geophysical archaeological prospection is generally considered as the attempt to locate structures of archaeolo- gical interest, in many cases, when applied in modern urban centres, this attempt is bound to fail due to the effect and disturbances caused by recent man-made structures in the subsoil overshadowing any signal caused by structures of archaeological interest. Modern underground structures (e.g. bars and slabs of reinforced concrete, metallic pipes, cables and associated trenches and building debris) occurring at shallow depth often display a stronger contrast in physical properties relative to the surrounding subsoil than less well expressed archaeological structures, which furthermore often are buried at greater depth.

Archaeological geophysical prospection in urban centres can be successfully employed to locate those regions that have been least affected by ground disturbances in modern or historical times. While it is only in few cases possible to detect in modern cities pre-historical archaeological structures directly using GPR, the mapping of those regions which have the greatest chance to contain preserved, undisturbed archaeological remains and cultural layers can be of great value to archaeological research, exploration and rescue archaeology and planning authorities alike. In combination with a detailed analysis of historical maps this inverse archaeological prospection approach is suited to maximise efficiency and value of archaeological excavations in urban centres. Information shown in town and city maps of the last decades and centuries can be of great use for the correct identification of anomalies contained in urban GPR data. Agreement between location, orientation and size of structures depicted in maps with reflective anomalies can indicate foundations of houses, backfilled cellar rooms, the former course of streets and sewers. While traditional maps generally show the location of roads, buildings and structures over ground, GPR data can be used to generate maps of underground structures.
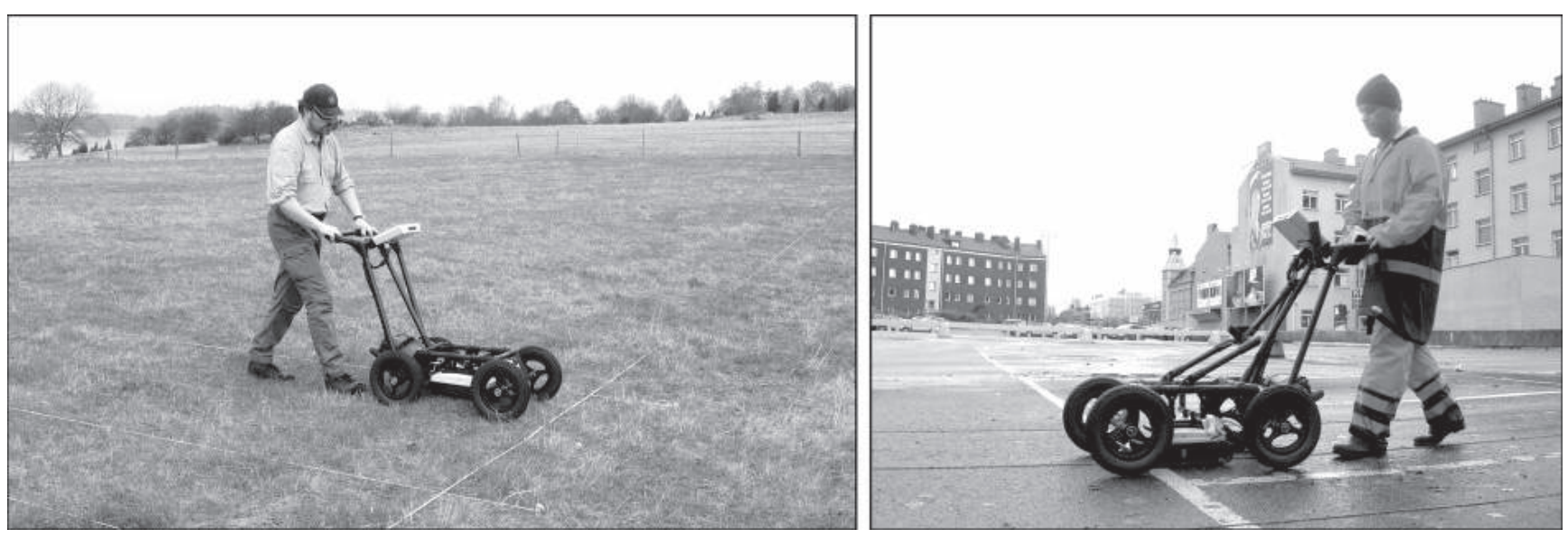

Figure 1: GPR surveys in the urban centre of the Viking town Birka (left) and in the city of Norrköping (right). 


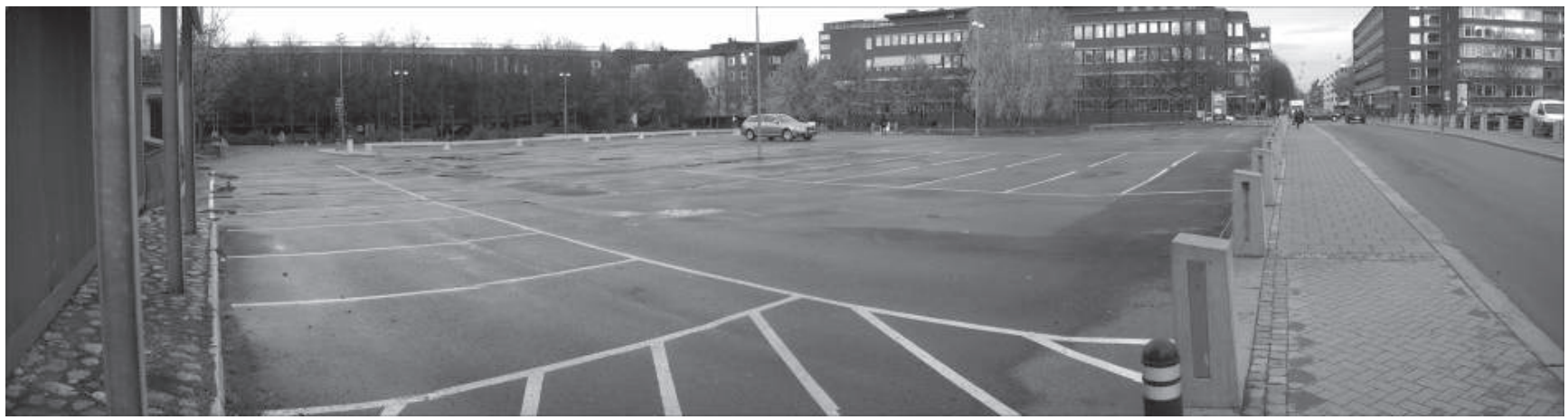

Figure 2: View of the survey site in Norrköping. The data shown in fig. 3 was acquired on this parking space.

Town planning, for example in connection with reconstructions after devastating blazes, can have caused changes in the layout of roads and quarters in towns. GPR data may display anomalies and structures which based on their orientation are likely to be belonging to one or the other layout, permitting their relative dating and identification as structures of archaeological interest.

Challenges for archaeological GPR prospection in modern city centres lie in the large number of obstacles present in urban environments. Kerbstones, traffic islands, metallic gully covers, lamp posts, buildings, trees and parked vehi- cles cause irregular survey geometries, holes in the survey area and disturbing anomalies in the GPR data. Variations in surface cover (asphalt, paving, sand, gravel, grass) affect the subsoil and lead to differences in GPR signal amplitudes. Standing surface water after rainfall on asphalt, even only centimetre deep, can cause strong signal reverberations throughout the entire recording time window. Pedestrian and vehicle traffic require especial attention when placing survey lines and measurement tapes. Particularly the closure of large parking areas can lead to irritation of the public and business owners and possible losses of parking charges
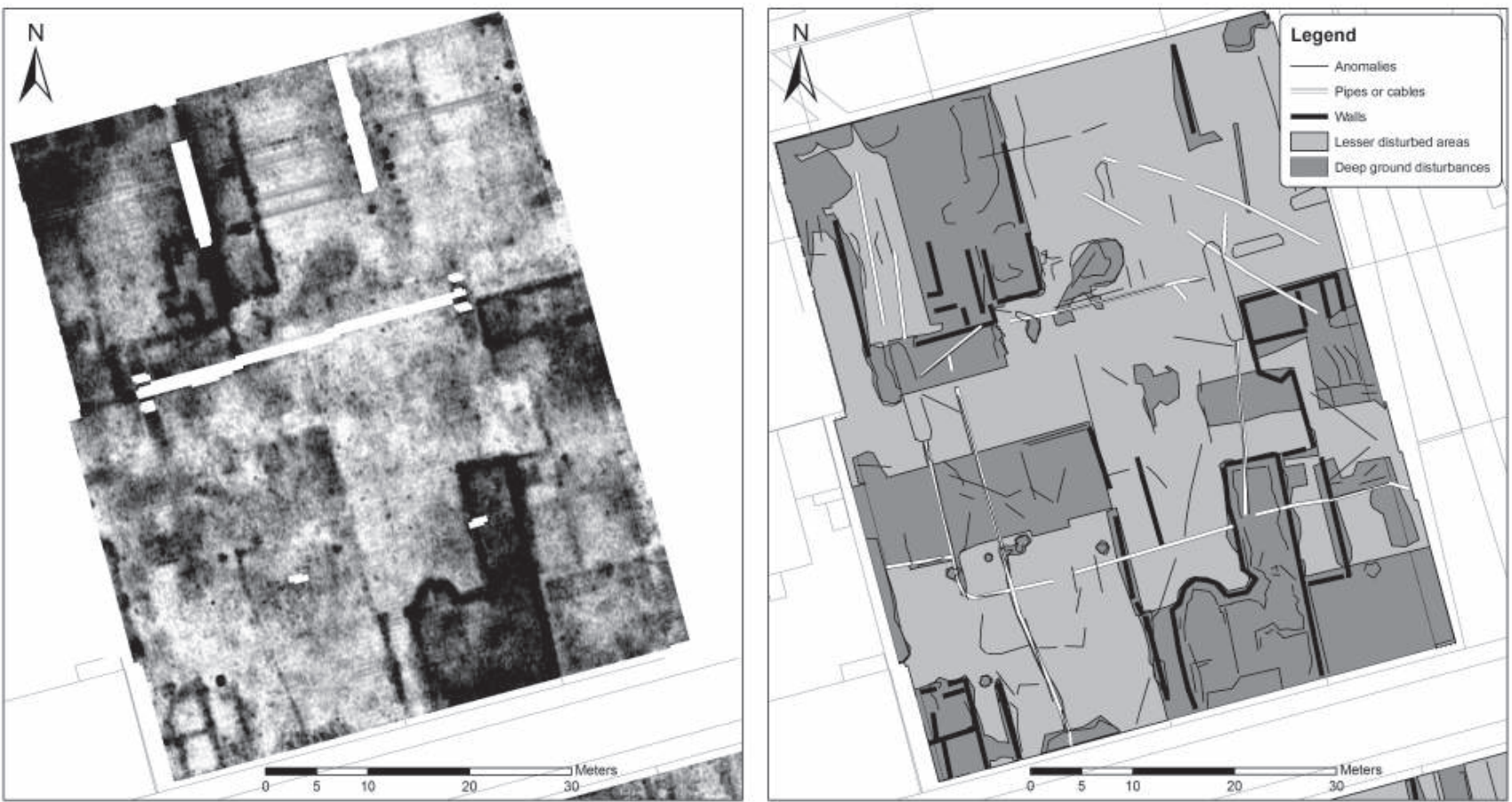

Figure 3: GPR depth-slice from approximately $120 \mathrm{~cm}$ depth (left) and data interpretation showing foundation walls, backfilled cellar rooms, and cables and pipes in the urban centre of Norrköping (right). The light coloured areas in-between deep ground disturbances have the highest potential to contain preserved, coherent cultural layers and archaeological structures. 
for operating companies. The timing of surveys should take into account important dates such as pay-days and mayor shopping periods (e.g. the pre-Christmas period) in order to minimize the disturbing effects of parking area closures.

\section{Data examples from urban centres}

Over the past four years several large scale high-definition GPR surveys have been conducted by the archaeological prospection unit of the Swedish National Heritage Board in the Swedish towns of Gothenburg, Kalmar, Norrköping and Nyköping, as well as in the Dutch towns of Venlo and Wijk bij Duurstede. These surveys were conducted on large parking areas, roads, pavements and adjoining grass strips. Using throughout a $500 \mathrm{MHz}$ antenna system (Sensors \& Software Noggin ${ }^{\text {Plus }}$ ) with a cross-line profile spacing of $25 \mathrm{~cm}$ more than five hectares of survey area were covered and in total over 200 line kilometres of GPR data acquired and processed.

We present data examples typical for large scale GPR surveys conducted in modern central European urban centres, illustrating both archaeological structures, such as foundation walls of town ramparts and structures belonging to older town layouts, as well as commonly encountered modern structures in the urban subsoil. The approach of inverse archaeological prospection will be illustrated with data acquired in the city of Norrköping (Fig. 2 and 3).

\section{References}

Becker, H. and Fassbinder, J. W. E., 1999. In Search for Piramesses - the Lost Capital of Ramesses II. in the Nile Delta (Egypt) by Cesium Magnetometry. Arbeitsh. Bayer. Landesamt f. Denkmalpfl., 108: 146-150.

Erkul, E., Rabbel, W. and Stümpel, H., 2003. Combined geophysical survey at Selinus, Sicily. Archaeologia Polona, 41: 157159.

Heimdahl, J., Menander, H. and Karlsson, P., 2005. A New Method for Urban Geoarchaeological Excavation, Example from Norrköping, Sweden. Norwegian Archaeological Review, 38(2): 102-112

Heimdahl, J. and Pettersson, C., 2007. Från sumpig lyx till torrlagd misär. Populär arkeologi, 3: 9.

LeCKebusCh, J., 2003. Ground-penetrating Radar: A Modern Three-dimensional Prospection Method. Archaeological Prospection, 10(4): 213-240.

Neubauer, W., Eder-Hinterleiter, A., Seren, S. and Melichar, P., 2002. Georadar in the Roman Civil Town Carnuntum, Austria: An Approach for Archaeological Interpretation of GPR Data. Archaeological Prospection, 9(3): 135-156.

Nishimura, Y. and Goodman, D., 2000. Ground-penetrating radar survey at Wroxeter. Archaeological Prospection, 7(2): 101-105.

Schliemann, H., 1881. Ilios - The city and country of the Trojans. New York, Harper \& Brothers. 